\title{
Shareholders' Duty of Loyalty and Positive Voting Duty
}

\author{
Borut Bratina, Dušan Jovanovič \\ University of Maribor, Maribor, Slovenia
}

\begin{abstract}
In the last decades, the number of corporate failures has been witnessed. As a rule, all the responsibility was laid on corporate officers and directors, while no one took into consideration possible breaches, committed by the shareholders. However, exactly such shareholders' conduct played a substantive role in many critical situations, since every essential decision regarding the company's rehabilitation is ultimately in their hands, through their right to vote on the general meeting. Moreover, the only shareholders' duty standing vis-à-vis such an immense power is their capital subscription. As a result, corporations are saturated with irresponsible shareholders that, in critical times for the company, ruthlessly follow only their own interest, largely ignoring preferences and benefits of other shareholders and, more importantly, the needs of the company itself. Consequently, the topic of this paper is to draw attention to the development of shareholders' duties and their responsibility to uphold rehabilitation measures, which stems from the duty of loyalty towards the company and fellow shareholders. The main research question was whether the shareholders have any obligation to the company after the establishment and how can such a liability for them be developed. The paper is based mainly on the German and Dutch legal theory and case law (comparative-law method), since both jurisdictions have already made a big step towards full acknowledgment of duty of loyalty. Even more, in special circumstances German legal practice recognizes also the duty to vote positively (positive Stimmpflicht). Eventually, the paper in short presents practical applicability of the findings. After such an analysis, our idea was to suggest a new corporate institute for adoption into Slovenian Company Law.
\end{abstract}

Keywords: duty of loyalty of shareholders, insolvency, positive voting duty, rehabilitation measures

\section{Introduction}

In the time of global financial crisis, an increasing number of companies are facing solvency problems. Especially exposed are the companies that were operating with a high degree of financial leverage, which, in case of a positive business performance, offered their shareholders substantial benefits. However, in time of a deteriorated business performance, a great systemic risk is posed by a corporate governance regime where shareholders participate in company's losses only until the value of their shares reaches zero, while all subsequent losses are incurred by the company's creditors. Such a regime promotes moral hazard amongst shareholders (and managers) who believe that high risks are worth taking in order to achieve expected profits

Borut Bratina, Ph.D., associate professor, Faculty of Economics and Business, University of Maribor.

Dušan Jovanovič, Ph.D., assistant professor, Faculty of Economics and Business, University of Maribor.

Correspondence concerning this article should be addressed to: Dušan Jovanovič, Ph.D., assistant professor, Faculty of Economics and Business, University of Maribor, Address: Razlagova ulica 14, 2000 Maribor, Slovenia. E-mail: dusan.jovanovic@uni-mb.si. 
and thus implicitly encourages taking exceeding risks, especially through powerful financial leverage. ${ }^{1}$ Consequently, legislation should impose a stricter and broader set of legal duties on shareholders as regards their part in performing the measures necessary especially for the rehabilitation of the company. ${ }^{2}$ It needs to be pointed out that financial problems force companies to perform not only financial restructuring measures, but also corporate restructuring measures, which exceed management's competence and fall within the direct competence of shareholders. For a majority of such measures to be approved, the qualified majority on the general meeting are required. However, a number of companies are structured in a way that the control share is held by only one owner or a linked group of owners (such an entity is frequently the state), which gives them the power to independently block the approval of a rehabilitation measure, necessary to prevent the company from becoming insolvent. Additionally, one should not overlook the rising influence of minority shareholders who, in certain circumstances, also have the power to block passing and performance of material measures. It needs to be pointed out that owners generally try to pursue their own interest and do not act in company's or other shareholders' benefit, whereas the objective detriment, caused to all the stakeholders (mainly creditors), greatly exceeds the individual benefit, obtained by that owner.

Shareholders therefore have the power to decisively influence the company's destiny and the interests of other share and stakeholders, which gives rise to the question as to whether they have the right to follow exclusively their own interests or they are bound by the duty of loyalty towards the company and fellow shareholders, forcing them to consider also the preferences and benefits of these stakeholders. The situation can be manifestly illustrated through the collision of principles of autonomy and fairness (De Jongh, 2012), which could possibly result in a duty, imposed on individual shareholders, not to obstruct a particular rehabilitation measure and, what is more, vote in its favor.

\section{Shareholders’ Duties and Rights in General}

As regards (public) companies limited by shares, corporate law in general pays much more attention to the duties of corporate officers and directors than to those of shareholders (Anabtawi, 2009; Bratina, Jovanovič, Podgorelec, \& Primec, 2011). Generally, the main and only duty of shareholders is their capital subscription (Kunze, 2003). Considering the fact that decisions regarding rehabilitation measures cannot be adopted and performed without shareholders' consent in form of a general meeting's resolution, such a regime could be easily described as disproportionate, especially when one takes into account a wide range of rights, granted to the shareholders. ${ }^{3}$ Namely, in correspondence with their portfolio of management rights, shareholders are empowered to decide on most important decisions, divided into two classes - those that are expressly enacted in legislation as part of shareholders' competence and those that are not explicitly mentioned and incorporated but cannot be decided solely by the management due to their high importance (as was decided in the

\footnotetext{
1 European Commission; Green Paper: The EU corporate governance framework, Brussels, 5.4.2011, COM(2011) 164 final: 10.

2 The latest change of the Slovenian Insolvency Law (Zakon o finančnem poslovanju, postopkih zaradi insolventnosti in prisilnem prenehanju-ZFPPIPP (F)) is very much a copy of the idea of French law to autonomous financial restructuring and produces the new rights and duties of shareholders how they are obligated to prove the loyalty to the company. Those new measures are provided for medium and big companies and meant only for financial debts (Art. 20. A and 44. B ZFPPIPP).

3 Property rights (e.g., the right to dividends), management rights: the right to demand information and to be given information, control rights, voting right, participation right, the right to challenge resolutions adopted by the annual general meeting.
} 
Holzmueller and Gelatine cases). ${ }^{4}$ It is exactly these kinds of decisions that are essential in time of the global crisis, since rehabilitation measures predominantly fall within the two aforementioned classes and are therefore in the competence of shareholders.

It is also adequate to make a distinction between majority and minority shareholders. Whereas the power of control held by the first-mentioned was never doubtful, the power of control held by the minority shareholders has risen significantly through the last decades and has drawn a lot of attention. While in some cases majority shareholders have the power to adopt the decisions (almost) autonomously and independently, minority shareholders can, when acting jointly, have de facto control over major decisions due to their possibility to block the adoption (blocking minority). ${ }^{5}$ Furthermore, every single shareholder is entitled to challenge any company's resolution in court, which can lead to fatal postponement of performance of essential measures. It is true that in certain cases such challenges are legitimate, however, in many cases the only goal of shareholders that initiate the proceedings is gaining (short-term) profit. ${ }^{6}$ Minority shareholders in public companies are consequently often interpreted as free agents, at liberty to try to influence corporate policy as they see fit-including trying to influence corporate policy in ways that favor their own interests over those of the corporation and other shareholders (Anabtawi, 2009).

Due to the nature of companies limited by shares, where the interests of shareholders are very heterogeneous, and due to the ability of shareholders to influence (harm) the interests of other constituencies, it would be more appropriate to take the duty of loyalty into consideration and sometimes demand from the shareholders to act not only in accordance with the fairness principle, ${ }^{7}$ but also in accordance with the principle of autonomy. ${ }^{8}$

\section{Shareholders' Duty of Loyalty in the Company Limited by Shares}

The duty of loyalty of shareholders can be defined as the duty to take into consideration interests of the company and other shareholders while refraining from any action that could harm them (Kunze, 2003). In short, it compels shareholders to act in accordance with the principle of fairness. It needs to be stressed that duty of loyalty is not limited solely to situations where shareholder's pursuit of his own interest would present an abuse

\footnotetext{
${ }^{4}$ Holzmueller (Holzmueller case (BGH) decision II ZR 174/80, 25.02.1982) and Gelatine (Gelatine case (BGH) decision II ZR $155 / 02$, 26.04.2004 and (BGH) decision, II ZR 154/02, 26.04.2004) cases are regarded as pioneer cases in the field of the unwritten shareholders' competence regarding business decisions. According to these decisions the management is not entitled to take material measures which alter the structure of the corporation and thus significantly affect the rights and interests of the shareholders, without the consent of the shareholders meeting (even if the law does not explicitly provide for such a consent requirement). In the Gelatine case the court was more precise and ruled that the approval of the shareholders meeting is only required in exceptional cases which constitute a fundamental structural change equivalent to an amendment to the company's articles of association. As decided, the disposal of less than $50 \%$ of the assets involved does not trigger this requirement (exact threshold and valuation parameters were left open). Where shareholder approval is required, the measure must be approved by a (qualified) majority of $75 \%$.

5 Because most of the rehabilitation measures must be adopted with a qualified majority, even a minority shareholder vote can be essential. In companies with thousands of shareholders the proxy voter collects votes of many minority shareholders and can therefore reach a significant share of votes.

${ }^{6}$ A shareholder threatens to challenge an important resolution, which would delay performance of a certain measure, if the company does not pay him a large amount of money (under the veil of attorney costs). In Germany this became a business trend amongst minority shareholders (predatory shareholders).

7 The shareholders have to keep an eye on the interests of the company and of other corporate constituencies.

${ }^{8}$ Shareholders may put their own interests first when exercising their shareholder rights. Such a principle is recognized by the First Protocol of the European Convention on Human Rights, which provides that everyone has the right to undisturbed enjoyment of his possessions, including the rights attached to a share. However, it does not mean that a shareholder can violate other persons' rights.
} 
of rights (Sorensen, 2010), since such a principle is already recognized in the EU law, as it can be deduced from the Diamantis case (European Court of Justice decision, 20009 ; Lenaerts, 2010), but stretches well beyond this principle.

When trying to answer the question whether such a duty exists in any of the present legal systems, an insight into German legislation is more than appropriate, since German legislation is regarded as most important and influential in the continental corporate law. The duty of loyalty there originates in the law of unincorporated companies, where such a duty is natural due to their sole nature, building on a tight connection between partners and their personal liability for any debts of the company. Fischer, a long standing judge of the Federal Court of Justice of Germany, described the duty of loyalty as the elemental duty that has its roots in the mutual trust and reliance among partners, which gives it special value (Hartwig, 1996). However, legal author Hueck (1947) presented his opinion that there is no space for duty of loyalty among shareholders, due to the different nature of their structure. Over time, in German literature, the duty of loyalty slowly became recognized not only in the sphere of unincorporated companies but also in the sphere of limited liability companies (where it is not questionable nowadays), however, it has been steadily declined or only very reservedly approved with respect to companies limited by shares. Since the reasons for such position can be found in the specific internal organization of the company limited by shares and the alleged lack of power of the (minority) shareholders, one must, especially in time of the financial crisis, take into consideration the fact that their power is heavily increasing. Moreover, if law can impose fiduciary duties to anyone who has the power to control the property of other persons (corporate officers and directors, for example), there are not many reasons why the same regime could not be enacted regarding shareholders, who also possess a great amount of control over the most important decisions that can crucially affect the company and other shareholders.

In US law, outlines of shareholders' duty of loyalty can be found in the 1969 case Jones v. H. F. Ahmanson Co., ruled by the California Supreme Court, which stated that the "majority of shareholders may not use their power to control corporate activities to benefit themselves alone or in a manner detrimental to the minority", while "any use to which they put the corporation or their power to control the corporation must benefit all shareholders proportionately and must not conflict with the proper conduct of the corporation's business". In 1981, the Appeals Court of Massachusetts went even further in the case Smith v. Atlantic Properties, Inc. to say that "[...] a stockholder may not act out of avarice, expediency or self-interest in derogation of their duty of loyalty to the other stockholders and to the corporation". Therefore, the extension of fiduciary duties to shareholders to some extent exists in the US law, however, it is still in the phase of development (Anabtawi, 2009).

The situation is different in EU law. Even though several duties of shareholders are enacted, they are all very specific in nature and do not amount to a general duty of loyalty (Sorensen, 2010). However, there were opinions according to which the shareholders of credit institutions, who own more than $10 \%$ of the capital or voting rights, have a general duty of loyalty (Werlauff, 2003). Today, this duty is enacted in Article 21(2) of Directive 2006/48/EC of 14 June 2006 relating to the taking up and pursuit of the business of credit institutions (OJ 2006 L 177/1), ${ }^{10}$ which reads:

\footnotetext{
9 European Court of Justice decision C-373/97, 23. 03. 2000.

${ }^{10}$ Directive 2006/48/EC of 14 June 2006 relating to the taking up and pursuit of the business of credit institutions (OJ 2006 L $177 / 1$.
} 
The Member States shall require that, where the influence exercised by the persons referred to in Article 19(1) is likely to operate the detriment of the prudent and sound management of the institution, the competent authorities shall take appropriate measures to put an end to that situation. Such measures may consist in injunctions, sanctions against directors and managers, or the suspension of the exercise of the voting rights attaching to the shares held by the shareholders or members in question. (Sorensen, 2010, pp: 128)

A closer look at the recent developments in the German legal system reveals important modifications of the state mentioned at the beginning of this section, which emerged especially on behalf of the decisions in the Linotype (BGH decision II ZR 75/87, 01.02.1988) ${ }^{11}$ and Girmes (BGH decision_II ZR 205/94, 20.03.1995) ${ }^{12}$ cases, where the Federal Court of Justice of Germany expressly recognized the duty of loyalty. In the Lynotype case, the court explicitly recognized the duty of loyalty of a majority shareholder towards the company, however, the decision can also be understood as though it confirms the duty of a majority shareholder towards other shareholders as well, yet, it does not answer the question whether there is a general duty of loyalty amongst other (e.g., minority) shareholders. Nevertheless, one could assume that the same regime would be enforced in case of a minority shareholder with de facto control over a certain decision (Hartwig, 1996). Such position was fully confirmed in the Girmes case, where the court ruled that the duty of loyalty is proportionate to the influence of the shareholder concerned. It is therefore clear that the duty of loyalty exists in the German legislation, not only towards the company, but also in relation to other shareholders, and covers not only majority, but also minority shareholders, as was decided by the Higher Court of Frankfurt, which ruled that minority shareholders are obliged to indemnify the damage caused by obstructing the planned capital increase (High court of Frankfurt decision, 2009) ${ }^{13}$. Additionally, duty of loyalty of shareholders is recognized also in the Dutch legal theory (De Jongh, 2012) and case law, where Versatel and Waterspreng cases are of special importance.

In the two most important legislations, the US and the German, duty of loyalty of shareholders in companies limited by shares is much more than just an idea. While in the German legal system the duty of loyalty towards the company is not questionable, certain legal theorists still doubt in its suitability as regards relations towards other shareholders. Nonetheless, the German (and Dutch) pattern should serve as guidance to other European countries in order to introduce a more solid type of corporate governance by redefining shareholders' duties. If responsible corporate governance wants to be achieved, such measures are unavoidable.

\section{The Effect of the Shareholders' Duty of Loyalty}

In order to emphasize the importance of duty of loyalty, it is prerequisite to analyze its practical effect. Even though there are basic elements that compose the core of the duty of loyalty, it needs to be pointed out that the intensity of duty's application depends on the circumstances of every particular case, such as the company's structure, position of its shareholders ${ }^{14}$, and their composition.

Weighing of circumstances in particular cases can be seen as collision between the principles of autonomy and fairness, which could, according to De Jongh (2012), be resolved with application of the principle of proportionality, pursuant to which shareholders may act in their own interest, provided, however, that they do

\footnotetext{
11 German Supreme Court (BGH) decision II ZR 75/87, 01.02.1988.

12 German Supreme Court (BGH) decision II ZR 205/94, 20.03.1995.

13 High court of Frankfurt decision 5 U 183/07, 13.01.2009.

14 The more influence shareholders have, the more they are obliged to take into consideration the interests of the company and other constituencies.
} 
not disproportionally harm the interests of the company and of other constituencies. To simplify the principle's practical application, it can be further divided into three components, the suitability test, ${ }^{15}$ the necessity test ${ }^{16}$, and proportionality in narrow sense ${ }^{17}$ (De Jongh, 2012).

In German legal system, an additional step forward has been made, resulting in development of the positive voting duty (positive Stimmpflicht). It presents a more decisive execution of the duty of loyalty (or the Dutch proportionality principle), allowing for interference with shareholders' voting rights, which makes it exceptionally relevant as regards issues with rehabilitation measures during the financial crisis. The positive voting duty, which in essence presents a shareholder's duty to vote for a specific measure under certain conditions, arises from the duty of loyalty towards other shareholders (Winkler, 2008) and is still controversial in the German literature. However, introduction of such a duty greatly limits fast-profit seeking investors and offers substantial security to the responsible ones. It should not be overlooked that a number of banks and other important public companies have found themselves in problems when trying to perform capital and other rehabilitation measures, because the shareholders were not willing to save the healthy parts of companies and stayed passive or even actively opposed and obstructed such measures. In many cases, opposition of shareholders is excusable, however, sometimes their objections are a clear result of their self-willingness. In such cases, application of the positive voting duty presents a suitable and effective remedy. Additionally, such a duty could successfully eliminate shareholder opportunism (Anabtawi, 2009), when occasional share buyers have no other interests than the short-term profit, which frequently leads to undue obstructions and poses a serious threat to the development of the company concerned.

\section{Positive Voting Duty}

Since the right to vote presents one of the fundamental rights of shareholders, it can be limited only in rare special cases. In accordance with the principle of autonomy, shareholders have full discretion to decide whether they will vote and thus exercise their voting right, and if they choose to do so, shareholders are allowed to freely decide which proposition will get their vote. However, pursuant to the duty of loyalty, in certain cases shareholders are obliged to consider not only their own interests, but also the interests of the company and other shareholders. Accordingly, when shareholder's interests are not affected by the measure or are harmed less than those of the company, if the measure was not performed, shareholder must not only actively take part in the voting process, but must also vote in a specific way (positive Stimmpflicht) (Winkler, 2008). ${ }^{18}$ Nevertheless, such obligation is imposed only in exceptional situations, mainly regarding decisions essential for the company's existence, or when shareholder's opposite activity could be defined as abusive (Kunze, 2003; Winkler, 2008).

It is the position of certain German legal authors that such a duty to vote in a specific way to some extent presents a breach of the constitutionally guaranteed right to private autonomy (Nehls, 1993). However, irrespective of such criticism, German legal practice is evolving in a way that acknowledges the duty of loyalty in the companies limited by shares, as well as the positive voting duty (Winkler, 2008). Yet, since in companies limited by shares, the connection between owners is decisively weaker than in other companies, conditions for application of the duty of loyalty and the positive voting duty have to be stricter. Consequently, in every

\footnotetext{
15 If a shareholder promotes a resolution which damages interests of others while offering him no or limited interest, the resolution will not pass the suitability test.

16 Of two broadly equally suitable means, the one that interferes less with the interest of others should be applied.

17 Establishing an abstract hierarchy between the two conflicting principles (autonomy and fairness).

${ }_{18}$ See also aforementioned cases of the BGH and BGH, 31.05.2011, II ZR 116/10 and BGH, 23.03.1987, II ZR 244/86.
} 
particular case, the two elements, objective and subjective, need to be fulfilled. According to the first, the decision as such has to be of essential importance for the company, ${ }^{19}$ while according to the second, the decision imposed must not (overly) affect the interests of the shareholder in question (Winkler, 2008). In order to impose the duty of loyalty, the interests of the parties involved need to be assessed in every particular case, possibly using the abovementioned suitability, necessity, and proportionality (in a narrow sense) tests, as established in the Dutch legal doctrine.

As presented, in Germany every investor (shareholder) in a company limited by shares is subject to the duty of loyalty towards both, the company and other shareholders, and must take into consideration also their interests. Reasonably, this duty affects shareholders in accordance with the power and influence they have in the company. The more influence a shareholder has in the company, the stronger the duty of loyalty that binds him is. Although the percentage of shares a shareholder owns generally indicates his power, it does not automatically mean that a shareholder with only a few shares has no influence, since minority shareholders can group and act jointly, while sometimes even a virtually inconsiderable number of shares suffice to block performance of important measures (e.g., predatory shareholders). It all depends on the circumstances of each particular case, which has to be individually assessed. However, the duty of loyalty and the resulting positive voting duty first need to be acknowledged and incorporated in the legal system, yet, by now, such approach to the duties of shareholders has been established only in German law.

\section{Practical Application of the Positive Voting Duty}

In German legal doctrine, authors are inconsistent regarding the authority which should have the power to enforce the positive voting duty (Kunze, 2003). According to the first group, the duty should be enforced by the chair of the general meeting, while the others uphold the opinion that it should be enforced by the court. It needs to be pointed out that the first option (or any other option that avoids regular court proceedings) seems much more effective, since the courts cannot guarantee a speedy enough resolution as required by the sole purpose of the positive voting duty, which could prevent the duty of loyalty from living up to its full potential.

Application of positive voting duty could facilitate passing and performance of essential rehabilitation measures, thus saving many companies in crisis. Furthermore, it would raise the capital quality, which is especially important in the banking sector, where the capital buffer needs to be strengthened in order for the banks to be able to withstand shocks, such as slumps in property prices or recession as is recently hitting Spain. The bar regarding capital standards for banks is constantly rising and the majority of banks will be subject to capital increase measures in the near future, however, many shareholders will not be willing to cooperate and participate in such measures. As a consequence, the new rules regarding capital buffers should be accompanied with suitable efforts to amplify shareholders' duties in relation to the company and other shareholders, where the duty of loyalty and the duty to vote positively, when voting on the rehabilitation measures, seem more than appropriate. In Germany, such new understanding of shareholders' position was established already years ago, while the Dutch system is also getting in place. The same should be done in other countries as well, in order to assure effective enforcement of the new capital rules for banks, to avoid numerous insolvency cases where companies could be rescued through rehabilitation measures and to stabilize the corporate governance systems in (public) companies limited by shares.

\footnotetext{
19 The question of essentiality is subject to case by case consideration. Undoubtedly, every decision connected to insolvency or legal death of the company and consequently to almost all rehabilitation measures is of essential nature.
} 


\section{Conclusions}

However, unacceptable unequal treatment of different kinds of shareholders may have been years ago, it is unavoidable nowadays, when interests of shareholders are growing more and more diverse and heterogeneous, mainly due to every shareholder primarily seeking (only) his own advantage. In general, the majority has the power to decide, yet, the steadily growing power of the minority should not be overlooked, especially regarding important decisions. It is crystal clear that a shareholder, who follows only his own interest and has de facto control in a specific situation, can cause immense and disproportional damage to both, the company and other shareholders. For a positive development of corporate governance systems in (public) companies limited by shares, it is imminent to limit some of the shareholders' rights or introduce preferential treatment of certain shareholders, especially the long-term shareholders. ${ }^{20}$ Such direction is also presented in the resolution adopted by the Reflection Group on the Future of EU Company Law, which suggests that in order to favor long-term share ownership and shareholder commitment, corporate legislation should be allowed to provide for long term shareholders preferential treatment. Positive voting duty presents execution of exactly such preferential treatment, imposing a duty on every shareholder to cooperate in the rehabilitation measures and act as a loyal shareholder. However unacceptable it may sound, one should be reminded that it is perfectly ordinary that management rights to vote are limited and damage liability is imposed in case when a shareholder fails to publish the mandatory takeover bid when the takeover threshold is met-would the same really be unimaginable also in order to prevent the company's rehabilitation from being obstructed?

\section{References}

Anabtawi, I. (2009). Fiduciary duties for activist shareholders. Law \& Economics Research Paper Series, No. 08-02.

Bratina, B., Jovanovič, D., Podgorelec, P., \& Primec, A. (2011). Law of Corporation and Business-Contract Law (Gospodarsko

Pravo družb in gospodarsko pogodbeno pravo). De Vesta: Maribor, 684+.

Cohen, Z. (1991). Fiduciary duties of controlling shareholders: A comparative view. The Journal of International Business Law, 12, 379-410.

De Jongh, M. (2012). Shareholders' duties to the company and fellow shareholders. European Company Law, 9(3), $185-191$.

Directive 2006/48/EC of 14 June 2006 relating to the taking up and pursuit of the business of credit institutions (OJ 2006 L $177 / 1$.

European Court of Justice decision C-373/97, 23. 03. 2000.

Gelatine case (BGH) decision II ZR 155/02, 26.04.2004 and (BGH) decision, II ZR 154/02, 26.04.2004.

German Supreme Court (BGH) decision II ZR 205/94, 20.03.1995.

German Supreme Court (BGH) decision II ZR 75/87, 01.02.1988.

Hartwig, H. (1996). Duty of Loyalty in Law of Corporation (Die Treuepflicht im Aktienrecht, Gedanken zur Rechtsprechung des Bundesgerichtshofes von "Kali und Salz" uber "Linotype" und "Kochs Adler" bis zu "Girmes"). Betriebs Berater, 10, 490-513.

High court of Frankfurt decision 5 U 183/07, 13.01.2009.

Holzmueller case (BGH) decision II ZR 174/80, 25.02.1982.

\footnotetext{
${ }^{20}$ Such a shareholders' duty/right position is even more important, if the company has financial problems. In that case we need to have a solution, that creditors can solve problems instead of shareholders, if they are passive. In that way of thinking the Netherlands Minister of Justice recently proposed legislation that would authorize the court appointment of a prospective trustee (beoogd curator) for a company prior to the commencement of formal insolvency proceedings for the purpose of exploring potential restructuring and/or sale opportunities. The proposal is part of a broader legislative initiative that includes a proposal for compulsory extrajudicial compositions and various measures designed to encourage the continuation and reorganization of insolvent companies.

The same idea leads the Slovenian legislator to adopt some new solutions in Slovenian Insolvency Act and Banking Law. When shareholders are without action for companies and their financial issues, creditors can take the leading part in the company.
} 
O’Donnell, J., \& Falloon, M. (2012). European Union breaks deadlock on bank rules. Retrieved from http://www.reuters.com/article/2012/05/15/us-eu-banks-capital-idUSBRE84E0WW20120515

Hueck, A. (1947). Mind of Loyalty in modern Private Law (Der Treuegedanke im modernen Privatrecht). Muenchen: Verlag der Bayerischen Akademie der Wissenschaften.

Kunze, D. (2003). Positive voting duty in Company Law (Positive Stimmpflichten im Kapitalgesellschaftsrecht). Frankfurt: Peter Lang Verlag.

Lenaerts, A. (2010). The general principle of the prohibition of abuse of rights: A critical position on its role in a codified European contract law. European Review of Private Law, 6, 1121-1154.

Nehls, A. (1993). Die gesellschaftsrechtliche Treuepflicht im Aktienrecht (Dissertation), Hamburg. Retrieved from http://www.strunk-kolaschnik.de/fileadmin/user_upload/AN-deutsch.pdf

Schmidt, K. (2002). Company Law (Gesellschaftsrecht), 4. Auflage. Köln: Heymanns Verlag.

Sorensen, K. E. (2010). Duty of loyalty of shareholders-A possible remedy for conflicts in SMEs? Company Law and SMEs, $10(1), 127-170$.

Werlauff, E. (2003). EU company law (2nd ed.). Copenhagen: DJOF Publishing.

Winkler, S. (2008). Responsibility of the Institutional Investors as Shareholders in Public Companies in Germany and USA. (Die Verantwortung institutioneller Anleger als Aktionäre in Publikumsgesellschaften in Deutschland und den USA). Frankfurt: JWV Jenaer Wissenschaftliche Verlagsgesellschaft. 